Marcin Puziak "Real convergence of new EU members. An experience for Ukraine", Journal of International Studies, Vol. 2, No 1, 2009, pp. 40-49.

\title{
Real Convergence of New EU Members. An Experience for Ukraine
}

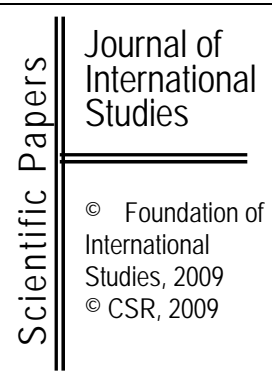

\author{
Marcin Puziak \\ Katedra Mikroekonomii \\ Uniwersytet Ekonomiczny w Poznaniu \\ marcin.puziak@ue.poznan.pl
}

\begin{abstract}
Economic growth is one of the most interesting research area of many economists. One of the most important subject, stemming from growth theory, is the theory of convergence. The main question of research is: do we live in a world in which poor countries tend to grow faster than the rich ones or contrary, in which poor countries stay poor and rich stay rich? Most common way of analysis limits to chosen group of countries, the idea known in literature as "convergence clubs". Convergence has many definitions, for purpose of this particular analysis the concept of absolute beta convergence and sigma convergence is used. The research presented in the paper is conducted among new EU members which joined European Union in 2004. The two exceptions are Cyprus and Malta which have different economical, political and cultural feature from other analyzed countries. In addition, analysis includes Ukraine. The degree of convergence is assessed on the basis of chosen economic indicators such as GDP per capita, GDP per capita growth rate, labor productivity growth rate and some auxiliary indicators. As a reference data, time series EU -15 is used. The analysis data derives from The Conference Board and Groningen Growth and Development Centre databases and covers period 1989 - 2006.
\end{abstract} $1^{\text {st }}$ revision: April, 2009 Accepted: June, 2009

Keywords: economic growth, macroeconomics, labor productivity.

JEL classification: O47 P2, P51

\section{Introduction}

One of the most important question raised by modern economics is: what are the determinants of wealth of nations? The theory of growth is trying to answer this question.

Over the last two decades the growth theory focuses mainly on convergence. The beginnings of convergence theory are dated starting 1986 when W. Baumol published his article "Productivity Growth, Convergence and Welfare: What the Long Run Data Show?", which underwent many continuations and changes over time. One of the most important factor boosting empirical research, both in the field of growth and convergence, was development of wide and comparable data bases (Maddison, 1982). Nonetheless, the research conducted didn't result in unambiguous conclusions. The question whether we live in the world in which poor countries (regions) tend to catch up with developed ones (Barro, Sala-iMartin, 1992) or poor countries stay poor, rich stay rich while middle class disappears (Quah, 1993) is still open. 
The article presents problems of convergence related to chosen economies of new EU members, which joined EU in 2004. These countries are: Czech Republic, Estonia, Latvia, Lithuania, Poland, Hungary, Slovenia and Slovakia. The analysis also includes Ukraine, because the auxiliary target of this article is to find conclusions for this economy. Due to the reasons mentioned above Malta and Cyprus were excluded from the reasearch. The background of the analysis is behavior of average EU-15.

The analysis bases on the idea of absolute beta convergence and sigma convergence. It is also aimed at verifying hypothesis weather analyzed economies catch up with EU-15, when GDP per capita and GDP per employee are considered.

The idea of absolute beta convergence stems from neoclassical theory of growth. This term refers to a situation in which initially poor counties experience rapid growth of GDP per capita in the later period. The verification of absolute beta convergence hypothesis requires an assumption that analyzed economies are homogenous. That means that they develop to common steady state. Sigma convergence hypothesis refers do GDP per capita dispersion. Confirmations of the hypothesis means that GDP per capita dispersion among analyzed countries decreases over time.

Analysis covers period 1989 - 2006 and in case of Ukraine the last observation is dated 2005.The length of analyzed period is subjected to the fact that many of the analyzed countries transformed from centrally planned to market economy after 1989. Data derives from The Conference Board and Groningen Growth and Development Centre, Total Economy Database (Groningen Database) databases. It should be noted that almost 20 year period of analysis is relatively short yet comparable to other researches in this field. The most frequently quoted research on convergence conducted by R. Barro and X. Sala-i-Martin cover period from 20 to 50 years (Barro, Sala-i-Martin, 1992). On the other hand, Mankiw, Romer and Weil analysis of growth and convergence was based on 25 years period (Mankiw, Romer, Weil, 1992). Taking the above mentioned into account there are two issues to be considered. At first, analyzed period is not long enough to state solid conclusions about economic growth and convergence process. Second is a credibility of data, especially from early 90 . when Czech Republic and Slovakia were one economy. In spite of the issues raised, one can answer question whether analyzed countries are catching up with developed EU members or not.

Analysis is divided into two parts. The first is aimed at comparing such variables as GDP per capita growth rate, GDP per capita level, labor productivity and hours worked level to average of EU-15 countries. Second part refers to above mentioned beta and sigma convergence hypothesis and is aimed at verification of real convergence hypothesis in selected economies.

\section{Results of economic growth in chosen economies analysis}

The main indicator for measuring economic growth is Gross Domestic Product per capita. Figure 1 presents changes of this indicator for nine chosen countries and average for EU-15, observed in the period 1989-2006. When analyzing the Chart one should take two characteristics into consideration. Firstly, transition process after 1989 is featured by high volatility of GDP per capita growth rate. The fluctuations of GDP per capita growth rate are volatile over the whole analyzed period and tend to smooth over time. Trends observed in these countries are significantly different from these observed in case of average for EU-15 which oscillates within $0-5 \%$. Secondly, negative GDP per capita growth rate in the initial phase of transition should be noted. Recession at the beginning of 90 . is commonly connected with „transition cost”. However, one has to notify that recession period was different among analyzed countries. The shortest period of negative GDP per capita growth rate was in Poland (ended in 1992) Czech Republic, Slovakia, Hungary and Slovenia (till 1993). 
The longest transition recession period was in Latvia, Estonia and Lithuania respectively. In case of Ukraine positive GDP per capita growth rate was observed only starting from 1998. Costs attributable to re-establishing market economy significantly varied over analyzed countries.

Figure 1. GDP per capita growth rate in chosen economies, 1989-2006

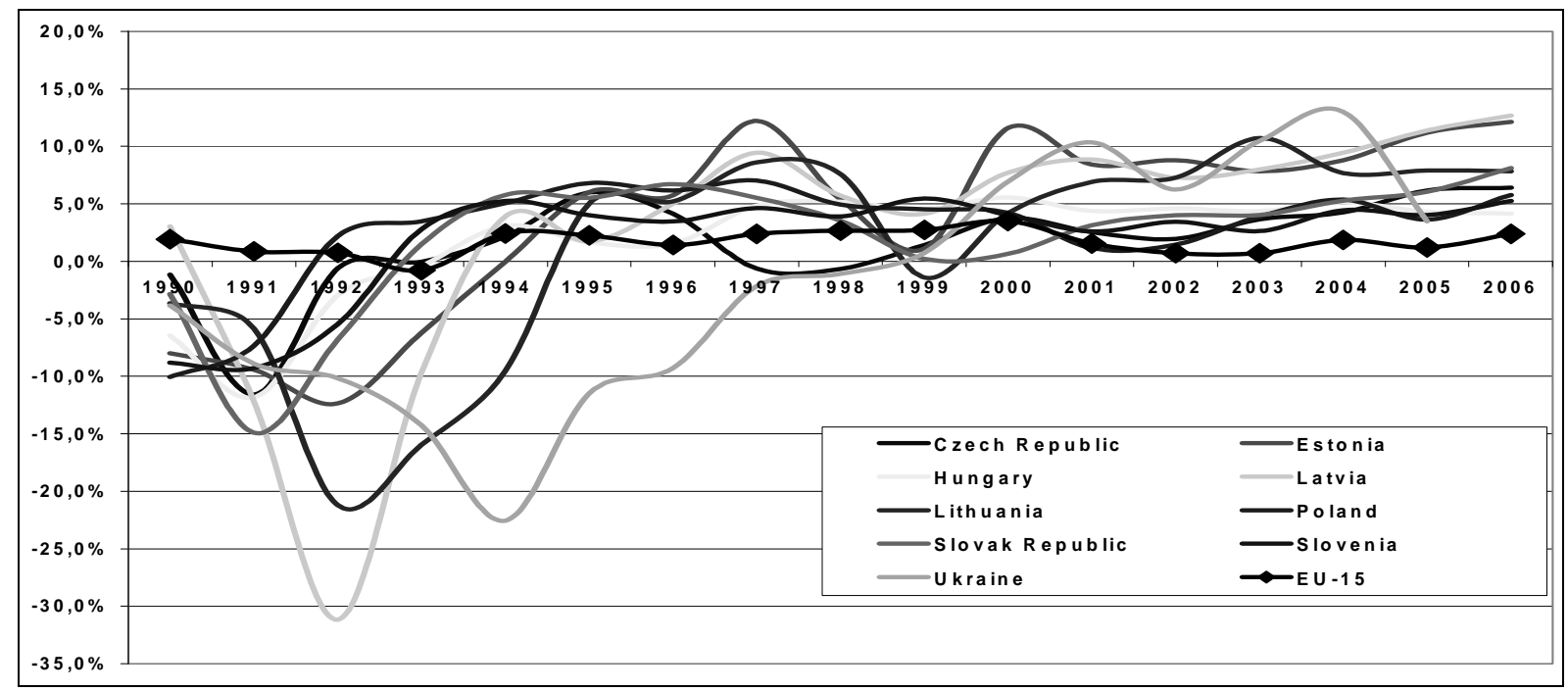

Source: Own compilation on the basis of Groningen Database

One has to notice the fact that high, positive GDP growth rate is not always correlated with welfare. Usually it is assumed that more accurate measure of welfare is GDP per capita level. Figure 2 presents level of GDP per capita in post-communist countries in comparison to average for EU-15, which is interpreted as a reference value.

Figure 2. GDP per capita level in chosen economies compared to EU-15 average, 1989-2006

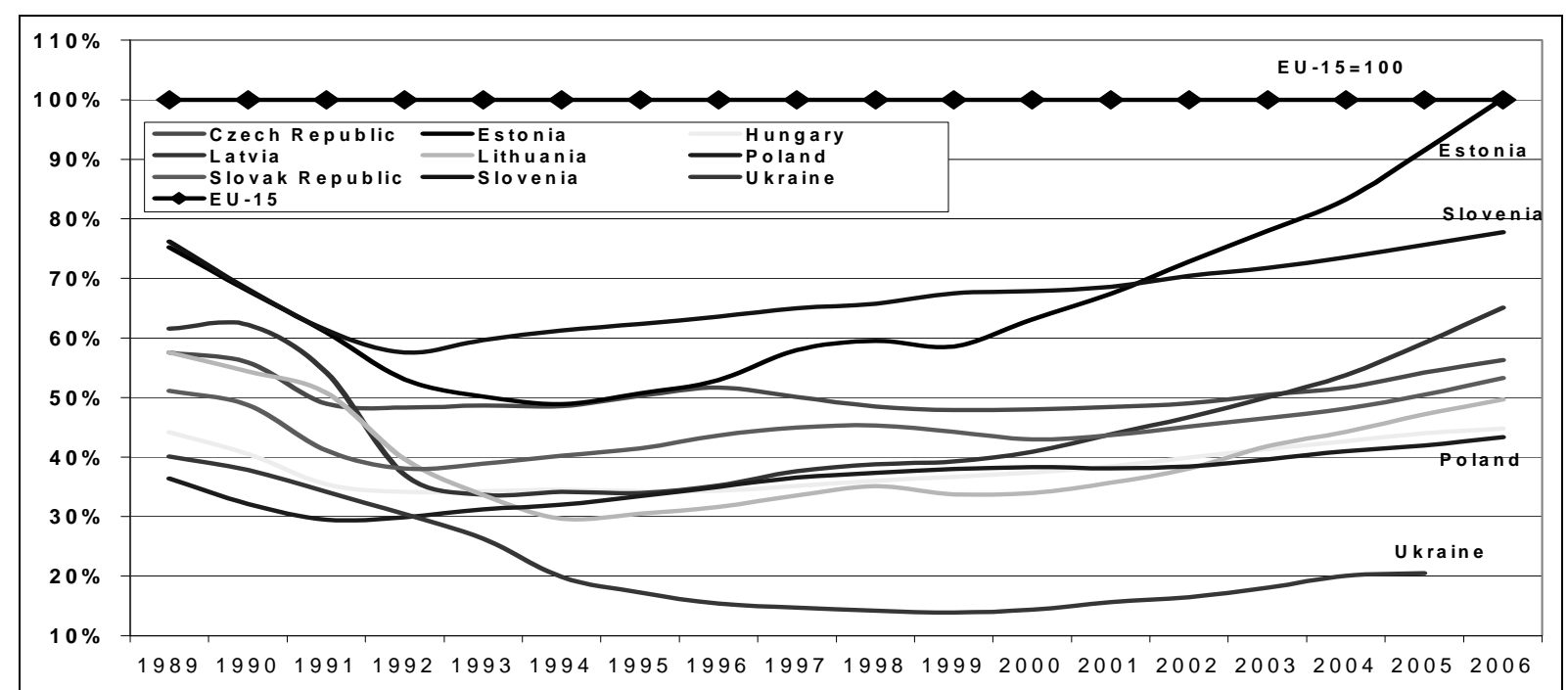

Source: Own compilation on the basis of Groningen Database 
The transition resulted in negative real GDP per capita growth in relation to EU-15 in the initial years. However, it has to be underlined that this was "socially accepted" cost. At the beginning of transition (1989 for the purpose of this paper) the closest to the EU-15 average were Estonia and Slovenia (with about $75 \%$ of EU-15 average level), while Poland and Ukraine had the worst GDP ratio comparing to EU 15 (below $40 \%$ of EU-15 average level). The initial decrease of real GDP per capita level in analyzed countries ended in the first half of 90 . After this period economies followed high growth path and started to catch up the lost distance.

Taking into account 18 years perspective one can notice that Estonia has the best performance while Ukraine with initial level higher than Poland in 1989 has the worst. Considering catch up process (in relation to EU 15) it is clear that Czech Republic, Lithuania and Ukraine experienced divergence while other analyzed economies experienced convergence.

Moving forward to economic growth analysis based on productivity indicators, labor productivity ratio should be taken into account ${ }^{1}$. Figure 3 presents labor productivity levels in the analyzed economies in relation to EU-15 average. Without an in-depth analysis strong correlation between welfare (measured by GDP per capita level) and labor productivity level is noticed. In the majority of analyzed economies labor productivity level is closer to EU-15 average than in the case of GDP per capita level. This is a result of labor market's changes in post-communist countries. The transition process led to decrease of productivity and employment level. This situation is opposite when EU-15 average data is considered. Such a situation was not observed there. In the EU-15 labor productivity and total employment have grown simultaneously.

Figure 3. Labor productivity level in chosen economies compared to EU-15 average, 19892006

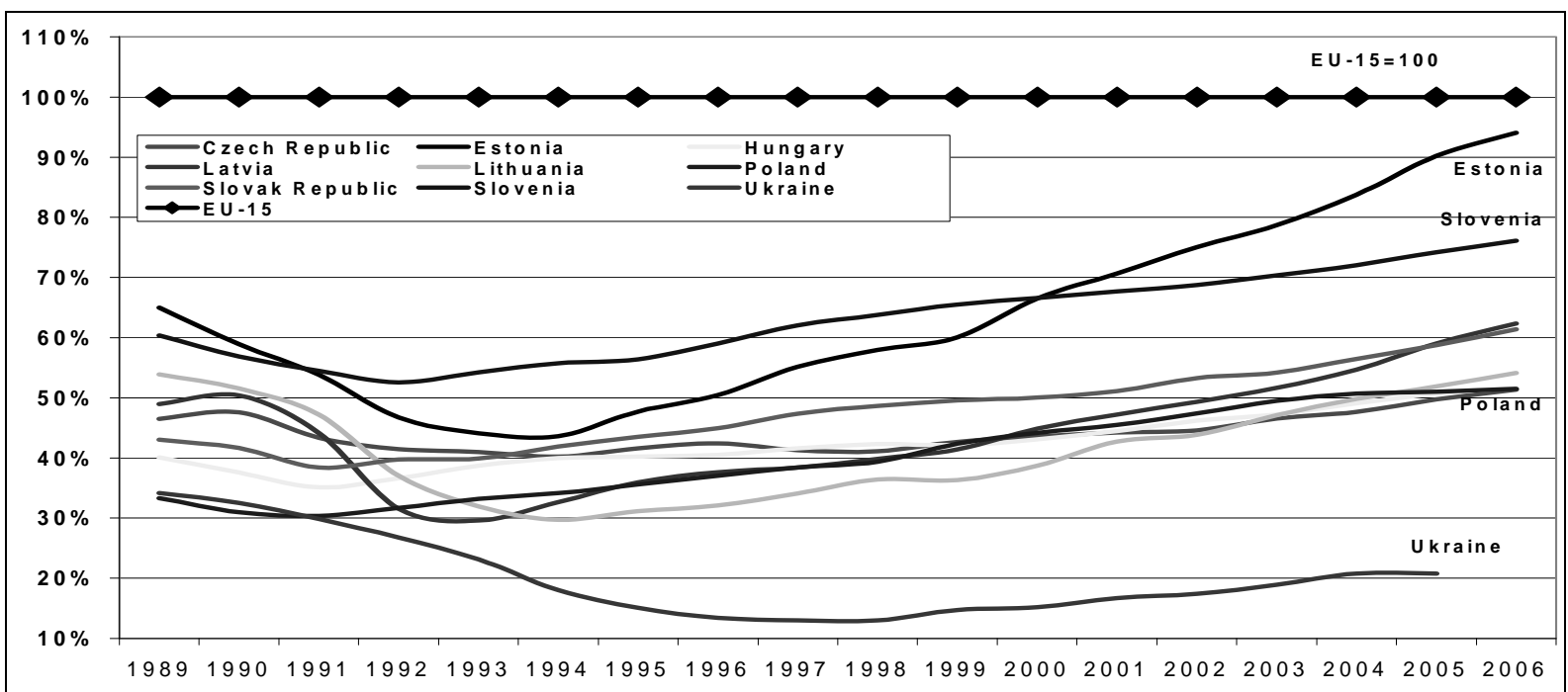

Source: Own compilation on the basis of Groningen Database

Initially, in 1989 the closest to the EU-15 average were Estonia and Slovenia (more than $60 \%$ of EU-15 average), while Ukraine, Poland and Hungary had much worse performance (less than $40 \%$ of EU-15 average). At the beginning of transition, decrease of real GDP was much deeper than decrease in number of employees, which resulted in decrease

\footnotetext{
${ }^{1}$ Labor productivity level is calculated as GDP per person employed
} 
of labor productivity level. Despite of fast economic growth, employment was still decreasing leading to labor productivity improvement.

Analysis of 18 years performance of labor productivity, shows that again Estonia had the best while Ukraine had the worst performance. Considering catch up process (in relation to EU 15) it is clear that in Ukraine experienced divergence while Lithuania sustained status quo, and the rest of countries reduced differences in labor productivity level.

While analyzing labor productivity level, hours worked per average employee must be taken into consideration. If labor productivity growth only results from longer work time it cannot be interpreted as enhanced work efficiency. Labor productivity is determined by labor, capital and their efficiency. According to this, Figure 4 presents number of hours worked in chosen economies compared to average for EU-15. Analyzing data shown at the Chart, it can be easily seen that not only hours worked in post communist countries diverged (in plus) from EU-15 average but also was significantly prolonged in relation to prior periods. This implies that achieved labor productivity growth in analyzed countries stems from extended working time.

Analyzing average worker efficiency, on the basis of Figures 3 and 4, one can notice that the highest productivity along with the highest number of working hours were observed in Estonia (more than $130 \%$ of EU-15 average). On the other hand, in Slovenia high labor productivity results from less number of hours worked (less than $110 \%$ of EU-15 average). Simplifying, one can assume that labor productivity is influenced apart from number of hours worked by technical progress and new methods in management. Combining more hours worked with new technologies and management methods results in faster catching up process (Estonia). In case of Slovenia one can see that less hours worked (as compared to Estonia) results in slower catching up process.

Figure 4. Number of hours worked in chosen economies compared to EU-15 average, 19892006

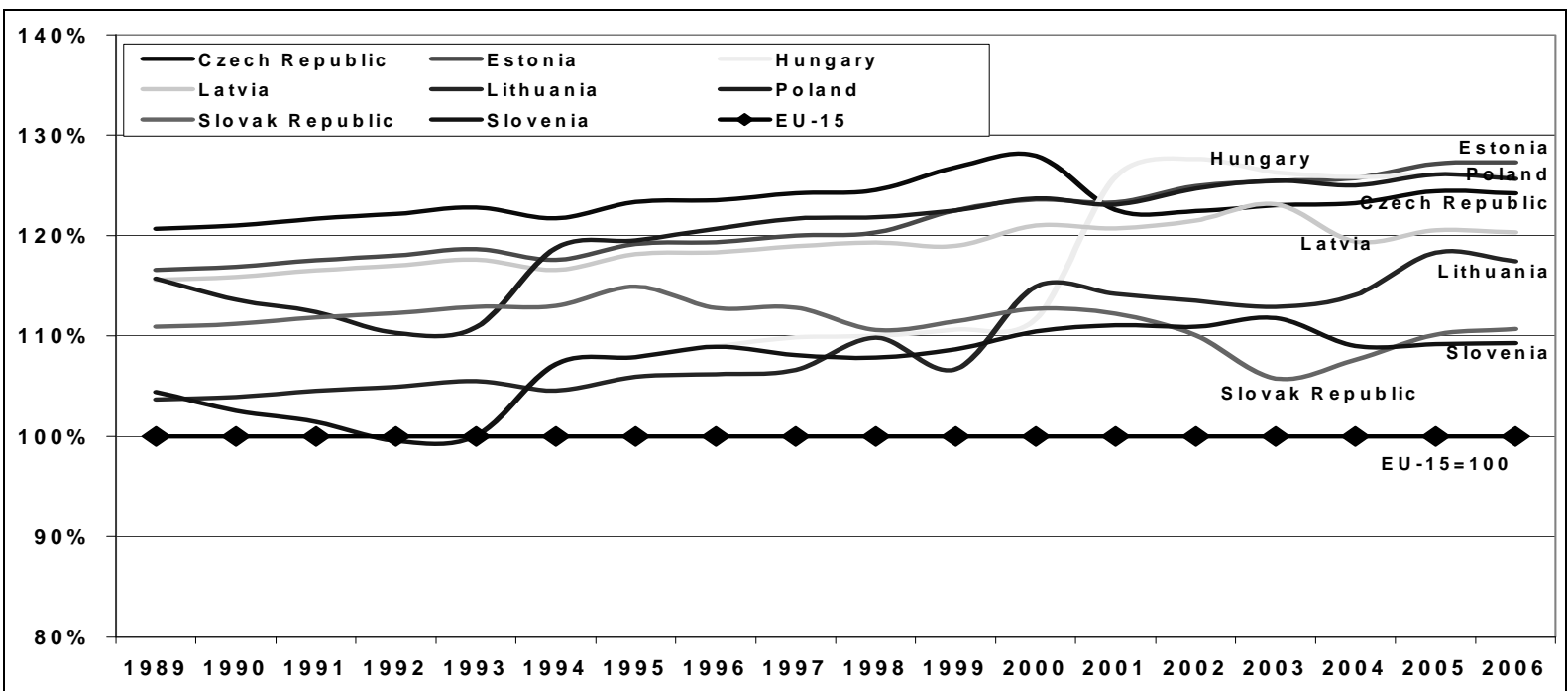

Source: Own compilation on the basis of Groningen Database

In case of Poland, two significant facts have to be taken into account. At first, polish economy is featured by the highest number of hours worked among analyzed countries, while labor productivity level is the lowest among new EU members. This fact can be explained by analysis of amount of physical capital per employee. The plausible explanation is the fact that in the EU-15 countries capital/employment ratio is much higher than in case of post 
communist countries. This allows EU-15 countries trimming the number of worked hours and simultaneously raising labor productivity. Accordingly, low capital/employment ratio in post communist countries results in bigger number of worked hours in order to catch up EU-15 level.

\section{Verification of absolute beta convergence and sigma convergence hypothesis}

Second part of the paper is aimed directly at the convergence problem in chosen economies. Two hypotheses were verified: absolute beta convergence and sigma convergence. Beta convergence states that there is a negative relationship between initial GDP per capita level/ labor productivity level and economic growth pace. If analyzed economies are assumed to be homogenous it implies that they would develop towards common steady state. In this case beta absolute convergence hypothesis is applied. If analyzed economies are different from each other considering such indicators as natural growth rate, savings rate, production costs, taxation, legal regulations, consumer preferences, government policy and degree of political freedom, one can state that each economy is developing toward its own steady state. In this case beta conditional convergence hypothesis is applied.

Beta convergence hypothesis can be verified either by estimation or calibration procedure. Both cases can be illustrated as shown in Figure 5.

Figure 5. GDP per capita growth rate 1989-2006 vs. 1989 GDP per capita level in chosen economies

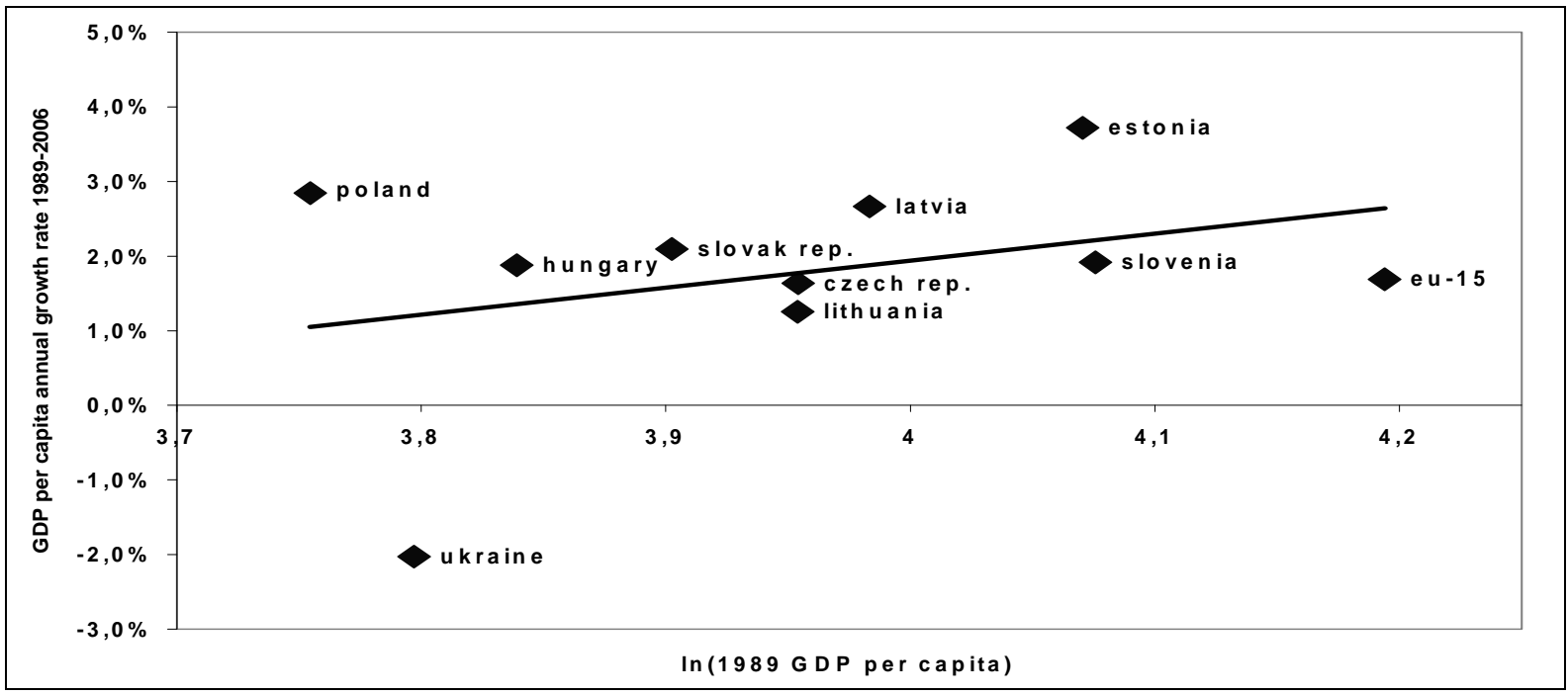

Source: Own compilation on the basis of Groningen Database

Figure 5 presents initial GDP per capita level compared to GDP per capita growth rate for each analyzed country. Positively oriented regression line indicates lack of beta convergence therefore, absolute beta convergence hypothesis has to be rejected.

The analyzed countries vary between each other. Criterion used for separation them into two more homogenous groups is political history. The first subset consists of former USSR republics while the other consists of countries that weren't the part of USSR. Beta convergence hypothesis verification gives different conclusion in both groups.

Analyzing data for Czech Republic, Slovakia, Slovenia, Poland and Hungary only one can state that beta absolute convergence is positively verified. Estimated regression line, presented in Figure 6 is negatively orientated that implies that countries with lower initial 
GDP per capita level experienced higher GDP per capita growth rate in the analyzed period.

Figure 6. GDP per capita growth rate 1989-2006 vs. 1989 GDP per capita level in economies outside former USSR

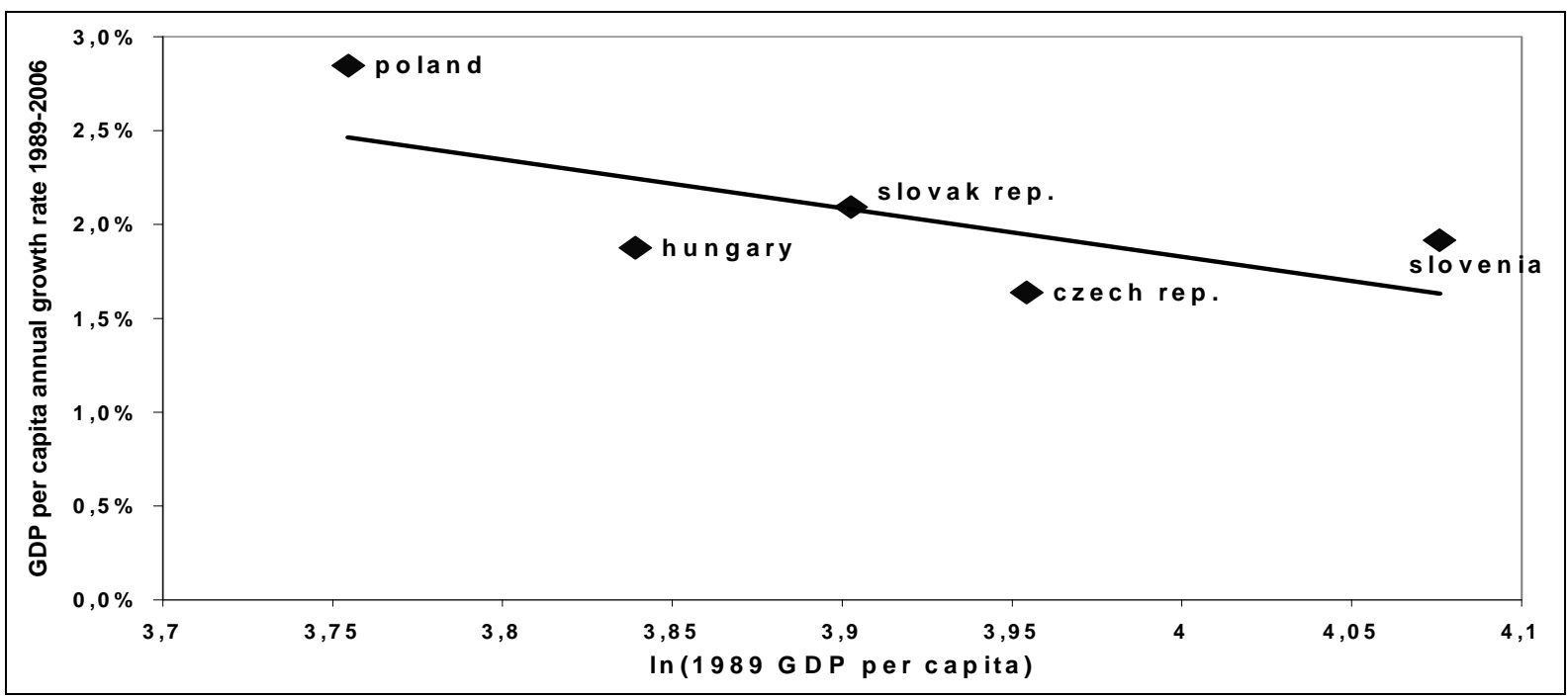

Source: Own compilation on the basis of Groningen Database

Analyzing data for Estonia, Lithuania, Latvia and Ukraine only one has to reject hypothesis of absolute beta convergence. Estimated regression line, presented on Figure 7 is positively orientated that implies that countries with higher initial GDP per capita level experienced higher GDP per capita growth rate in the analyzed period.

Figure 7. GDP per capita growth rate 1989-2006 vs. 1989 GDP per capita level in economies of former USSR

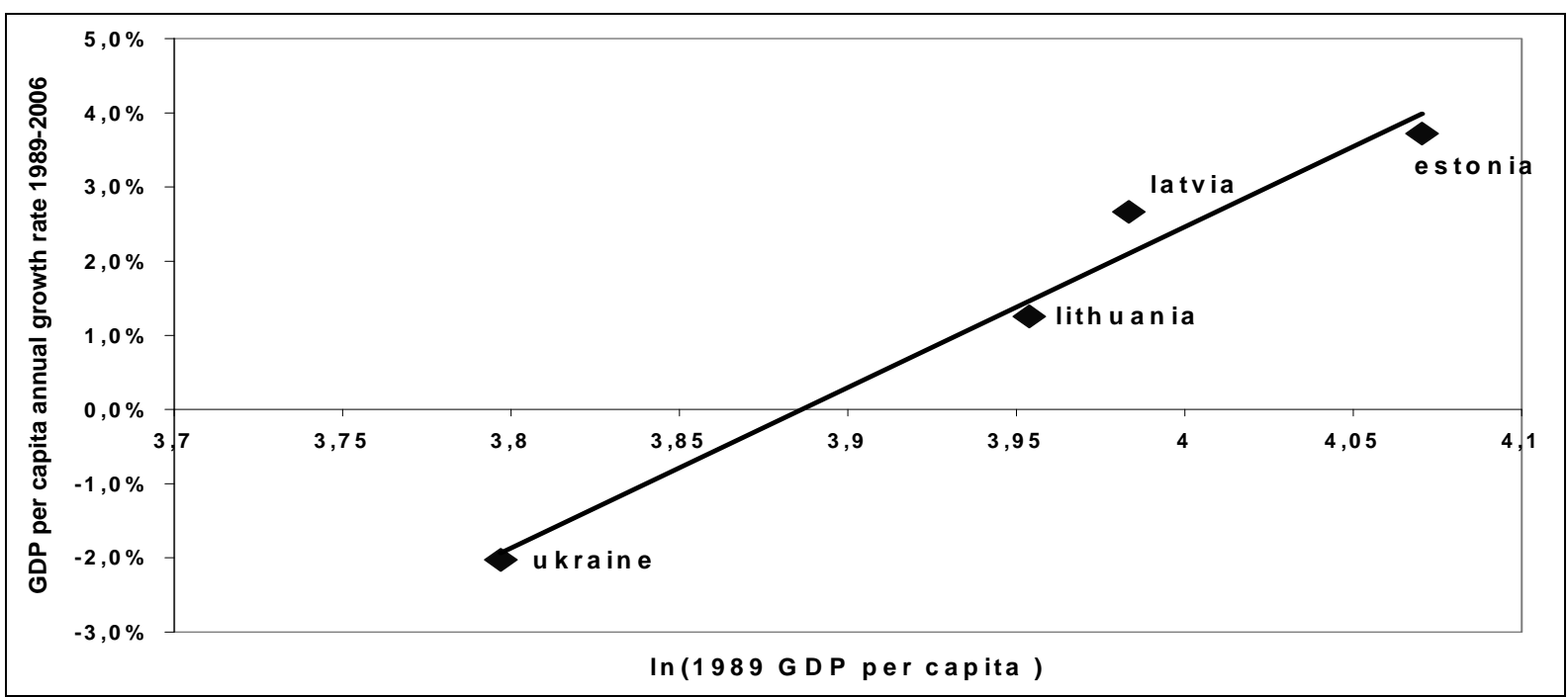

Source: Own compilation on the basis of Groningen Database 
Apart from beta convergence hypothesis verification the question arises whether in analyzed countries income distribution increases or decreases over time. The idea of sigma convergence attempts to answer this question (Malaga, 2004). The most commonly measure used for sigma convergence hypothesis verification is standard deviation of natural logarithms volatility observed over time.

Sigma convergence hypothesis implies that dispersion of GDP per capita is diminishing over time in analyzed group of countries. Research conducted by Barro and Sala$\mathrm{i}$-Martin confirms that sigma convergence is actually observed. However, research conducted by others economists show the opposite results (Quah, 1996).

Figure 7. Sigma convergence coefficients in chosen economies, 1989-2006

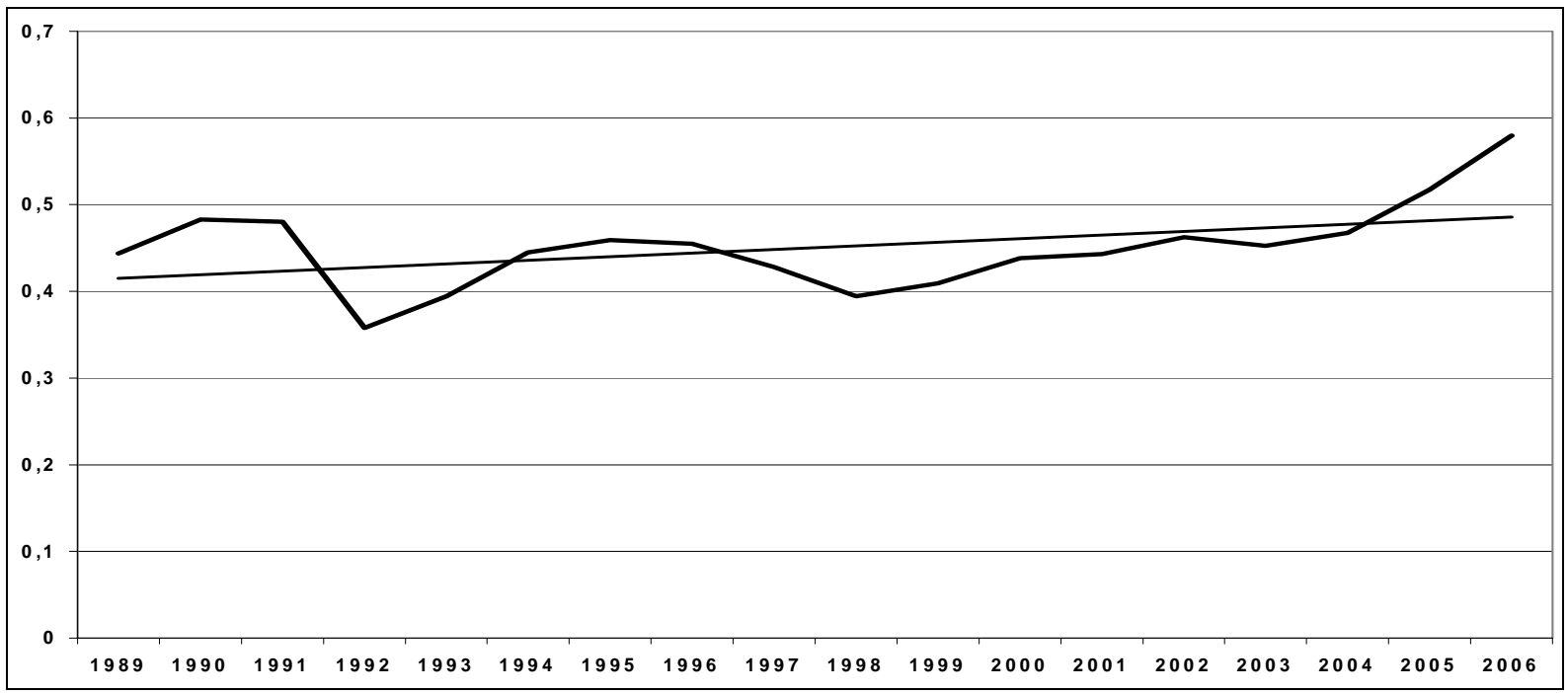

Source: Own compilation on the basis of Groningen Database

Figure 7 presents changes in sigma coefficients in all analyzed economies over the time period. Analyzing the data shown on the chart it can be noted that GDP per capita dispersion in all analyzed countries increases over time. Such results are opposite to sigma convergence hypothesis and can be interpreted as sigma divergence.

Figure 8. Sigma convergence coefficients for economies outside former USSR, 1989-2006

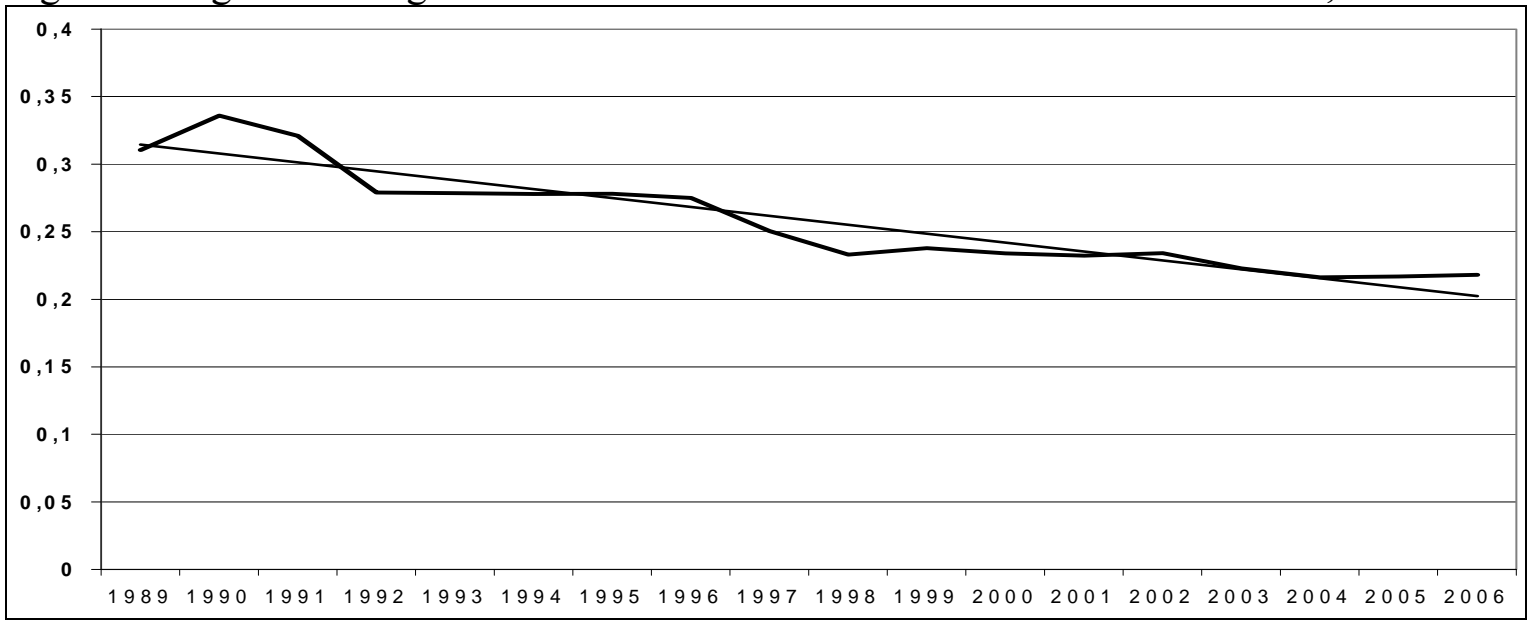

Source: Own compilation on the basis of Groningen Database 
Dividing analyzed economies into two subsets according to above mentioned criterion and analyzing them separately results in different conclusions. Basing on Czech Republic, Slovakia, Slovenia, Poland and Hungary (Figure 8) data, sigma convergence hypothesis can be positively verified. Trend line is negatively orientated which implies that dispersion of GDP per capita tends to decrease over time.

Figure 9. Sigma convergence coefficients for economies of former USSR, 1989-2006

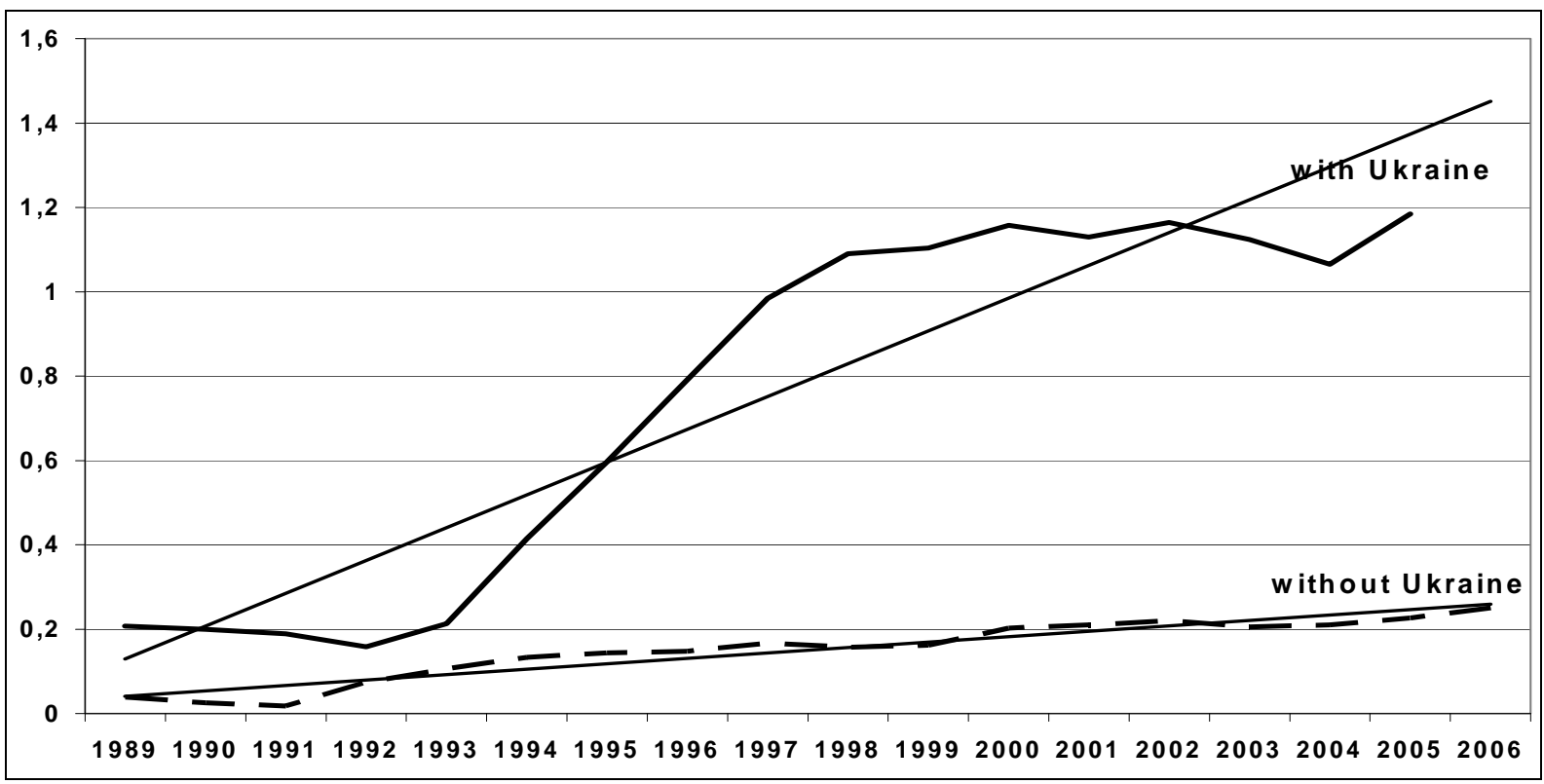

Source: Own compilation on the basis of Groningen Database

Basing on former USSR economies data hypothesis of sigma convergence should be rejected. Even if Ukraine's data (which had negative GDP per capita growth over most of analyzed period) is removed from the analyzed sample, dispersion of GDP per capita is still increasing.

The analysis of sigma convergence performed shows that economies that were not part of former USSR are more homogenous. Diminishing GDP per capita dispersion in this group of countries can be explained by undisturbed physical capital flows, greater employees mobility as well as similar technological and institutional development.

\section{Conclusions}

- All analyzed economies suffered from transition cost, caused by shock therapy, which resulted in negative GDP per capita growth. However, this should be treated as an inevitable step on the way to market economy;

- Catching up process was observed in the majority of countries, however it was diverse among the analyzed economies.

- Convergence process was possible mainly due to greater number of hours worked. Taking into account 18 years perspective the best performance was observed in Slovenian and Estonian economies;

- Both absolute beta convergence and sigma convergence hypotheses can be positively verified in case of countries outside of former USSR; 
- Taking into consideration socio-economical potential and structural problems a possible economic growth path for Ukraine is going to be similar to Polish economy experiences.

\section{References}

1. Abramovitz M., (1986), Catching Up, Forging Ahead, and Falling Behind, Journal of Economic History, June, 46, 385-406

2. Barro R., (1998), Determinants of Economic Growth, MIT Press, Cambridge; London

3. Barro R., Sala-i-Martin X., (1991), Convergence across States and Regions, Brookings Papers on Economic Activity, 1, 107-182

4. Barro R., Sala-i-Martin X., (1992), Convergence, Journal of Political Economy, April, 100, 223-251

5. Barro R., Sala-i-Martin X., (2004), Economic Growth, MIT Press, Cambridge; London

6. Baumol W., (1986), Productivity Growth, Convergence, and Welfare: What the Long Run Data Show, American Economic Review, December, 76, 1072-1085

7. Baumol W., Wolff E., (1988), Productivity Growth, Convergence, and Welfare: Reply, American Economic Review, December, 76, 1155-1159

8. DeLong B., (1988), Productivity Growth, Convergence, and Welfare: Comment, American Economic Review, December, 78, 1138-1154

9. Lucas R., (1988), On the Mechanics of Economic Development, Journal of Monetray Economics, July, 22, 3-42

10. Maddison A., (1982), Phases of Capitalism Development, Oxford University Press, New York, 1982

11. Malaga K., (2004), Konwergencja Gospodarcza w Krajach OECD w świetle Zagregowanych Modeli Wzrostu, Prace Habilitacyjne 10, Wydawnictwo AE, Poznań

12. Mankiw N., Romer D., Weil D., (1992), A Contribution to the Empirics of Economic Growth, Quarterly Journal of Economics, May, 107, 407-437

13. Quah D., (1993), Galton's Fallacy and Tests of the Convergence Hypothesis, Scandinavian Journal of Economics, 4, 95, 427-443

14. Quah D., (1996), Twin Peaks: Growth and Convergence in Models of Distribution Dynamics , Economic Journal, July, 106, 1045-1055

15. Rebelo S., (1991), Long-Run Policy Analysis and Long-Run Growth, Journal of Political Economy, June, 99, 500-521

16. Romer P., (1986), Incerasing Returns and Long-Run Growth, journal of Political Economy, October, 94, 1002-137

17. Solow R., (1956), A Contribution to the Theory of Economic Growth, Quarterly Journal of Economics, February, 70, 65-94

18. The Conference Board and Groningen Growth and Development Centre, Total Economy Database, November 2007,http:/www.conference-board.org/economics/ 